\title{
A Study on Hardfacing Alloy Using Fe-Cr and Fe-B Powders
}

\author{
E. KariP*, S. Aydin, M. MuratoĞLu \\ Firat University, Metallurgy and Materials Engineering, Elazig, Turkey
}

\begin{abstract}
The aim of this study is the investigation of the effect of ferroboron and ferrochromium with massive wire based hardfacing alloys. Mixture of $\mathrm{Fe}-\mathrm{Cr}$ and $\mathrm{Fe}-\mathrm{B}$ powders was added to massive wire during welding process. Hardface layers were obtained by three different powder mixture and three different powder/massive wire proportions. Hardfacing was applied to two AISI 1020 steel substrates by open arc welding. Hardness test, scanning electron microscope and X-ray diffraction analysis were made to the samples. Test results showed that increasing ferroboron content and increasing powder mixture amount enhanced the microhardness of the specimens.
\end{abstract}

DOI: 10.12693/APhysPolA.128.B-160

PACS: $81.20 . \mathrm{Vj}$

\section{Introduction}

Surfacing, as applied to welding technology, refers to the deposition of a filler metal on a base metal (substrate) to impart some desired property to the surface that is not intrinsic to the underlying base metal. Several types of surfacing exist: hardfacing, build up, weld cladding, and buttering. Hardfacing is a form of surfacing that is applied for the purpose of reducing wear, abrasion, impact, erosion, galling, or cavitation. Hardfacing alloys may be deposited by oxy fuel welding, various arc welding methods, laser welding, and thermal spray processes. Hardfacing materials include a wide variety of alloys, carbides, and combinations of these materials. Conventional hardfacing materials are normally classified as steels or low-alloy ferrous materials, high-chromium white irons or high-alloy ferrous materials, carbides, nickel-base alloys, or cobalt-base alloys [1].

Hardfacing is the application of a durable surface layer to a base metal to impart properties like resistance to metal-to-metal sliding with high contact stress, impact wear, abrasion erosion or pitting and corrosion or any combination of these factors $[2,3]$. Hardfacing can be applied by several techniques, such a plasma spraying, laser cladding, arc welding and thermal spraying methods $[2,4,5]$.

Iron-based alloys with molybdenum (Mo), titanium $(\mathrm{Ti})$, niobium $(\mathrm{Nb})$, in combination with boron $(\mathrm{B})$ and carbon $(\mathrm{C})$ have been selected as hardfacing alloys due to their high hardness and wear resistance gained by the precipitation of different abrasion resistant hard phases $[6,7]$. The high chromium irons are widely used for hardfacing of industrial components in mining, cement plant, thermal power plants and iron and steel industries due to their higher hardness and excellent abrasive resistance which were attributed to the formation of chromium carbides. The addition of alloying elements and rapidly solidified fine crystalline microstructure con-

*corresponding author; e-mail: erdogankarip13@gmail.com taining finely distributed hard phases can exhibit an excellent combination of hardness and toughness of the hardfaced alloys [8]. Coarse hard phases and high hardness are important to achieve high abrasion resistance. The hardness of the hard phases and/or the hardness of the matrix should be higher than the hardness of the abrasive $[8,9]$.

Borides are one of the promising alloys for increasing the surface hardness and the wear, oxidation and corrosion resistance of engineering components. Borides are the common hard phases in hardfacing alloys [10, 11]. Borides that form with the transition metals have long been known to possess high hardness and excellent wear, friction and corrosion resistance [12]. In literature some studies revealed that boron promoted the development of primary hard phases such as boride, increasing the volume fraction of these wear resistant hard phases [12-14]. Boride-rich cored wires are used widely in cladding or hard surfacing of some industrial applications by spraying or welding methods [15].

In this study, the effect of massive wire additional powder proportion ferrochromium and ferroboron have been investigated. In the present study $\mathrm{Fe}-\mathrm{B}$ powder was used as boron source with various proportions. Three different massive wire/powder ratios and three different $\mathrm{Fe}-\mathrm{B} / \mathrm{Fe}-$ $\mathrm{Cr}$ powder compositions were used. Hardfacing samples have been produced by open arc welding. Hardness test, scanning electron microscope (SEM) and X-ray diffraction $(\mathrm{XRD})$ analysis were made to the samples.

\section{Experimental method}

In the current study hardfacing samples were produced by open arc welding using massive wire $1.2 \mathrm{~mm}$ in diameter, $\mathrm{Fe}-\mathrm{Cr}$ and $\mathrm{Fe}-\mathrm{B}$ metallic powders on AISI 1020 steel. The powder mixture ratios used in the tests were shown in Table I.

Welding parameters were shown in Table II.

Chemical compositions of massive wire, $\mathrm{Fe}-\mathrm{B}$ and $\mathrm{Fe}-\mathrm{Cr}$ metallic powders were given in Table III.

Samples have been polished and etched with Kelling's reagent $\left(33 \mathrm{ml} \mathrm{HCl}, 33 \mathrm{ml} \mathrm{H}_{2} \mathrm{O}, 33 \mathrm{ml}\right.$ methyl alcohol 
TABLE I

Compositions of powder mixtures.

\begin{tabular}{c|l}
\hline \hline A & pure massive wire \\
B & $75 \%$ m. wire $-25 \%$ powder \\
B1 & m. wire + 100\% FeCr \\
B2 & m. wire + 90\% FeCr $-10 \% \mathrm{FeB}$ \\
B3 & m. wire + 60\% FeCr - 40\% FeB \\
C & $50 \%$ m. wire $-50 \%$ powder \\
C1 & m. wire $+100 \% \mathrm{FeCr}$ \\
C2 & m. wire + 90\% FeCr $-10 \% \mathrm{FeB}$ \\
C3 & m. wire + $60 \% \mathrm{FeCr}-40 \% \mathrm{FeB}$ \\
D & $25 \%$ m. wire $-75 \%$ powder \\
D1 & m. wire $+100 \% \mathrm{FeCr}$ \\
D2 & m. wire $+90 \% \mathrm{FeCr}-10 \% \mathrm{FeB}$ \\
D3 & m. wire $+60 \% \mathrm{FeCr}-40 \% \mathrm{FeB}$
\end{tabular}

TABLE II

Welding parameters.

\begin{tabular}{c|c|c|c}
\hline \hline \multicolumn{3}{|c}{ Welding parameters } \\
\hline voltage $[\mathrm{V}]$ & 25 & $\begin{array}{c}\text { travelling speed } \\
{[\mathrm{mm} / \mathrm{min}]}\end{array}$ & 150 \\
\hline $\begin{array}{c}\text { powder feeding rate } \\
{[\mathrm{g} / \mathrm{min}]}\end{array}$ & 60 & $\begin{array}{c}\text { oscillation width } \\
{[\mathrm{mm}]}\end{array}$ & 40 \\
\hline $\begin{array}{c}\text { wire feeding rate } \\
{[\mathrm{g} / \mathrm{min}]}\end{array}$ & 60 & current $[\mathrm{A}]$ & 200
\end{tabular}

and $1.5 \mathrm{~g} \mathrm{CuCl}_{2}$ ) for quantitive analysis of the carbideboride/matrix phases. Hardness test, SEM and XRD analysis were made to the samples.

\section{Results and discussion}

SEM micrograph of the hardfaced samples were given in Fig. 1. Also microhardness was given in Fig. 2.

In all samples it was observed that carbides and ironborides were dispersed in dendritic structure (Fig. 1). This is thought to be a factor in increasing the hardness.

As can be seen from Fig. 2, in general, the microhardness values showed rise for all the samples. However, a gradual increase was seen in the surface. Hardness values of $547.4 \mathrm{HV}, 733.6 \mathrm{HV}$ and $881.9 \mathrm{HV}$ in the surface were

\section{TABLE III}

Chemical compositions of samples.

\begin{tabular}{c|c|c|c}
\hline \hline \multicolumn{4}{c}{ Chemical compositions of massive wire } \\
\hline \% C & $\% \mathrm{Si}$ & $\% \mathrm{Mn}$ & $\% \mathrm{Fe}$ \\
\hline 0.1 & 0.6 & 1.1 & rest \\
\hline \multicolumn{4}{c}{ Chemical compositions of FeCr } \\
\hline$\% \mathrm{C}$ & $\% \mathrm{Cr}$ & $\% \mathrm{Si}$ & $\% \mathrm{Fe}$ \\
\hline 8 & 64 & 1 & rest \\
\hline \multicolumn{4}{c}{ Chemical compositions of $\mathrm{FeB}$} \\
\hline \multicolumn{3}{c}{$\% \mathrm{~B}$} & \multicolumn{3}{c}{$\% \mathrm{Fe}$} \\
\hline \multicolumn{2}{c|c}{10} & 90
\end{tabular}

measured for specimens B3, C3, and D3, respectively. Compared with the hardness values of the surface, this high hardness value in the samples can be related to the increase in $\mathrm{Fe}-\mathrm{B}$ powder content.

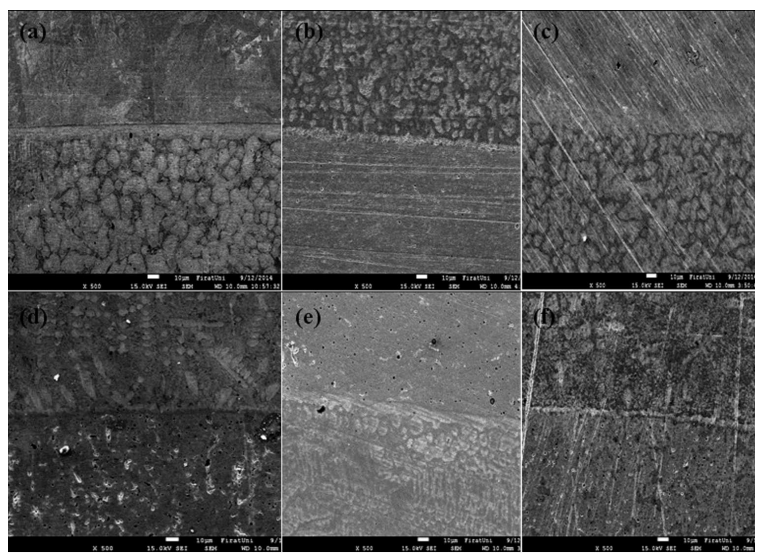

Fig. 1. SEM microstructure of samples: B2 (a), C2 (b), D2 (c), B3 (d), C3 (e) and D3 (f).

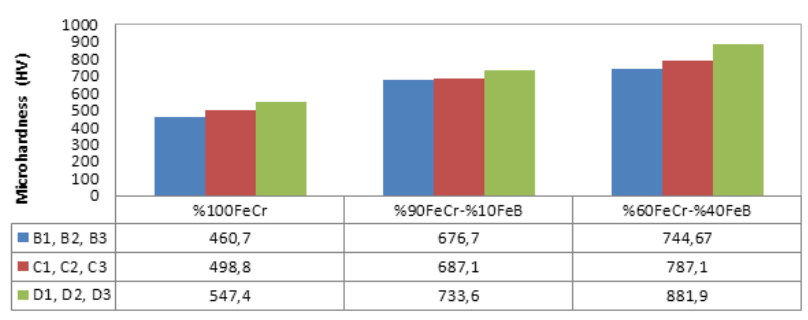

Fig. 2. Microhardness profiles of the samples (B, C, D).

It was observed that increasing volume fraction of carbides increased the microhardness with the increasing powder mixture content (Fig. 2). Also the presence of ferroboron showed a further increase in the microhardness when it was compared with the pure massive wire results (A). The formation of the carbides which include $\mathrm{Cr}$ and $\mathrm{B}$ element were observed, and so this increased the microhardness valve. Fe powder content was found more effective than increasing Fe powder content addition to enhance the formation of hard carbide phases.

The results of X-ray analysis were given in Fig. 3a and $b$. X-ray results showed that the sample of D2 with maximum boron content consisted of $\mathrm{FeCr}, \mathrm{Fe}_{3} \mathrm{C}$, $\mathrm{FeB}$ and $\mathrm{Cr}_{7} \mathrm{C}_{3}$ phases. Petrovic et al. reported that boron changes the thermodynamic conditions of the formation of the carbide nucleus and favors the formation of $\mathrm{M}_{3} \mathrm{C}$ and $\mathrm{M}_{23} \mathrm{C}_{6}$ carbides in the structure of chromium white irons [16]. Eroğlu has obtained maximum hardness value with maximum boron content sample produced by shielded metal arc welding method. He has reported that the hardness value of this sample is between 1450 and $1700 \mathrm{HV}$ [17]. When the $\mathrm{Fe}-\mathrm{B}[18]$ and $\mathrm{Fe}-\mathrm{Fe}_{3} \mathrm{C}$ [19] binary phase diagrams were considered, it can be seen that the phases transformed in the coating and transition zone of specimen were in good agreement with these 


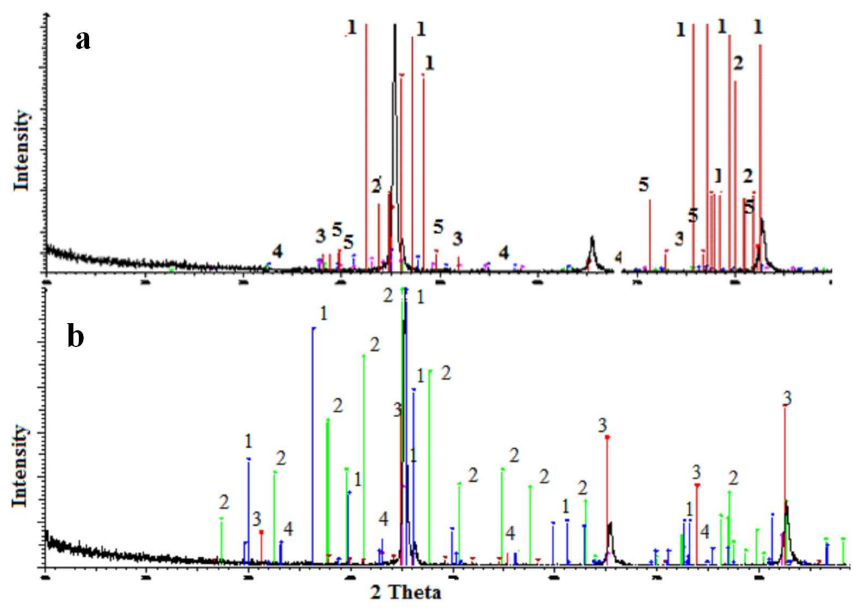

Fig. 3. (a) XRD patterns of sample D2: $1-\mathrm{FeCr}$, $2-\mathrm{FeB}, 3-\mathrm{Fe}_{3} \mathrm{C}, 4-\mathrm{CrB}, 5-\mathrm{Cr}_{7} \mathrm{C}_{3}$ and (b) XRD patterns of sample D3: $1-\mathrm{Cr}_{2} \mathrm{~B}_{3}, 2-\mathrm{FeB}, 3-$ cromeferrite $(\mathrm{Fe}, \mathrm{Cr}), 4-\mathrm{Fe}_{3} \mathrm{C}$.

phase diagrams. The difference in mechanical properties of these phases was also supported with microhardness measurements.

$\mathrm{X}$-ray results showed that the sample of D3 with maximum boron content consisted of $\mathrm{Cr}_{2} \mathrm{~B}_{3} \mathrm{Fe}_{3} \mathrm{C}$ and $\mathrm{FeB}$ phases. The samples obtained by this carbide reveals needle-like, rounded and close-packed primary borides corresponding to a hypereutectic composition, and it is thought to increase the microhardness of these phases.

The samples formed by $\mathrm{FeB}, \mathrm{CrB}$ and $\mathrm{Fe}_{3} \mathrm{C}$ phases are believed to cause hardening of the deposited material in small sizes at the grain boundary. The effect on the material of the phase was made in some studies; boron is the most effective element in increase of the hardness of the steel alloying.

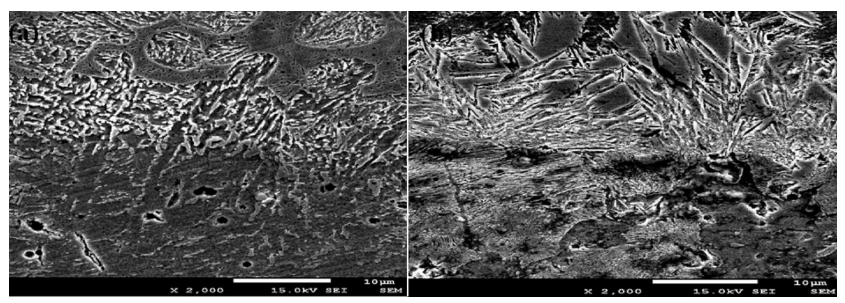

Fig. 4. SEM microstructure of samples: B1 (a) and D1 (b).

At higher chromium levels, typically above $30 \mathrm{wt} \% \mathrm{Cr}$, $\mathrm{M}_{23} \mathrm{C}_{6}$ carbides may nucleate and grow throughout a peritectic reaction between the liquid and $\mathrm{M}_{7} \mathrm{C}_{3}$ carbides, producing carbide with a core-shell structure $\left(\mathrm{M}_{7} \mathrm{C}_{3}-\right.$ $\mathrm{M}_{23} \mathrm{C}_{6}$ ) [14]. Dublex carbides were observed in the samples B1 and D1 that contain $36.88 \%$ and $51.32 \% \mathrm{Cr}$, respectively (Fig. 4a and b). Only $\mathrm{M}_{7} \mathrm{C}_{3}$ type carbide was detected in the XRD result of $\mathrm{B} 1$ and $\mathrm{D} 1$ samples. But according to energy-dispersive $\mathrm{X}$-ray spectroscopy (EDX) analysis, a significant difference of chromium con- tent in duplex carbides was determined (B1: Cr: 36.88, Fe: 54.52 and C: 8.6 and D1: Cr: 51.32, Fe: 34.31 and C: 14.37). As can be seen from that, the inner carbide phase (darker) includes more chromium and carbon than that of the outer carbide phase (lighter). Tang et al. observed that high chromium white iron (45 wt\% chromium) including $4 \% \mathrm{C}$ has a duplex structure consisting of a dark core and a lighter layer or shell. They reported that the core is $\mathrm{M}_{7} \mathrm{C}_{3}$ and the lighter shell is $\mathrm{M}_{23} \mathrm{C}_{6}$ [20]. Lin et al. applied wavelength dispersive spectrum analysis to $\mathrm{Fe}-\mathrm{Cr}-\mathrm{C}$ alloys and found that content of $\mathrm{M}_{23} \mathrm{C}_{6}$ phase is lower than $\mathrm{M}_{7} \mathrm{C}_{3}$ phase [21]. It was shown that $\mathrm{M}_{23} \mathrm{C}_{6}$ carbides exist in addition to $\mathrm{M}_{7} \mathrm{C}_{3}$ carbides $\mathrm{B} 1, \mathrm{D} 1, \mathrm{~B} 2$ and D2 samples, even they were detected by XRD.

Chromium content of hard phases reduced with increasing FeB content in powder mixture for B, C and $\mathrm{D}$ groups. Even though the increased boron content in hard phases and the decreased boron content in matrix were expected, it was unable to be determined exactly by EDX. Reduction of boron content in matrix was attributed to the formation of iron carbide $\mathrm{Fe}_{3} \mathrm{C}$ in $\mathrm{D} 2$. The same result was observed in B and $\mathrm{C}$ groups.

\section{Conclusion}

The microhardness of all samples was increased with increase of the used metallic powder. Hard faces such as $\mathrm{Cr}_{7} \mathrm{C}_{3}, \mathrm{Cr}_{2} \mathrm{~B}_{3}, \mathrm{Cr}-\mathrm{B}$ and $\mathrm{Fe}-\mathrm{Cr}$ were obtained using $\mathrm{Fe}-\mathrm{Cr}$ and $\mathrm{Fe}-\mathrm{B}$ powders.

The samples (B3, C3, D3) produced by $60 \% \mathrm{FeCr}-$ $40 \% \mathrm{FeB}$ powder addition without seeing massive wire/powder ratio exhibited maximum microhardness. As can be understood, increasing boron content promoted the growing of primary $\mathrm{Cr}_{7} \mathrm{C}_{3}$ and increased the volume fraction of hard phases, here by the hardness were enhanced.

Increasing powder addition, consequently increased B, $\mathrm{C}$ and $\mathrm{Cr}$ constants, affected the microstructure positively by supporting not only the development of primary carbides but also the formation of secondary carbides.

\section{References}

[1] R. Davis, ASM Handbook, Welding, Brazing and Soldering, Vol. 6, ASM International, USA 1993, p. 787.

[2] I. Khan, Welding Science and Technology, 1st ed., New Age International (P), New Delhi 2007.

[3] S.Y. Tu, M.D. Jean, J.T. Wang, C.S. Wu, Int. J. Adv. Manuf. Technol. 27, 889 (2006).

[4] H. Deng, H. Shi, S. Tsuruoka, Surf. Coat. Technol. 204, 3927 (2010).

[5] M. Shamanian, S.M.R. Mousavi Abarghouie, S.R. Mousavi Pour, Mater. Des. 31, 2760 (2010).

[6] M. Kirchgabner, E. Badisch, F. Franek, Wear 265, 772 (2008).

[7] G. Azimi, M. Shamanian, J. Mater. Sci. 45, 842 (2010). 
[8] E. Badich, C. Katsich, H. Winkelmann, F. Franek, M. Roy, Tribol. Int. 43, 1234 (2010).

[9] J.J. Coronado, H.F. Caicedo, A.L. Gomez, Tribol. Int. 42, 745 (2009).

[10] L. Lin, K. Han, Surf. Coat. Technol. 106, 100 (1998).

[11] B. Selcuk, R. İpek, M.B. Karamis, J. Kuzucu, J. Mater. Proc. Technol. 103, 310 (2000).

[12] J.W. Yoo, S.H. Lee, C.S. Yoon, S.J. Kim, J. Nucl. Mater. 352, 90 (2006).

[13] J.H. Kim, H.S. Hong, S.J. Kim, Mater. Lett. 61, 1235 (2007).

[14] R.J. Chung, X. Tang, D.Y. Li, B. Hinckley, K. Dolman, Wear 301, 695 (2013).
[15] M.H. Amushahi, F. Ashrafizadeh, M. Shamanian, Surf. Coat. Technol. 204, 2723 (2012).

[16] S.T. Petrovic, S.V. Markovic, S. Zec, J. Serb. Chem. Soc. 67, 697 (2002).

[17] M. Eroğlu, Surf. Coat. Technol. 203, 2229 (2009).

[18] P.K. Liao, K.E. Spear, ASM Handbook, Alloy Phase Diagrams, Vol. 3, ASM International, Materials Park, OH 1992, p. 81.

[19] H. Okamoto, in Ref. [18], p. 110.

[20] X.H. Tang, R. Chung, C.J. Pang, D.Y. Li, B. Hinckley, K. Dolman, Wear 271, 1426 (2011).

[21] C.M. Lin, H.H. Lai, J.C. Kuo, W. Wu, Mater. Charact. 62, 1124 (2011). 